\title{
The Widespread Distribution of the Venomous and Poisonous Blue-lined Octopus Hapalochlaena spp., in the East/Japan Sea: Possible Effects of Sea Warming
}

\author{
Ji Hoe Kim ${ }^{1 *}$, Toshiyuki Suzuki ${ }^{2}$, Kil Bo Shim ${ }^{1}$ and Eun Gyoung $\mathrm{Oh}^{1}$ \\ ${ }^{1}$ Food Safety Research Division, National Fisheries Research and Development Institute, Busan 619-705, Korea \\ ${ }^{2}$ Biochemistry and Food Technology Division, National Research Institute of Fisheries Science, Fisheries Research Agency, 2-12-4, \\ Fukuura, Kanazawa, Yokohama, Kanagawa 236-8648, Japan
}

\begin{abstract}
The geographical distribution of the toxic blue-lined octopus (commonly known as the blue-ringed octopus), Hapalochlaena spp., around the East/Japan Sea was investigated. Observation records of the octopus were gathered using commercial search engines on the Internet. A questionnaire to complement and enhance the base data was conducted that targeted fishermen from areas where the octopus was most likely to occur, i.e., the southeast coast and islands of Korea in the East/Japan Sea. Overall, 32 observational records of the blue-lined octopus were found from Korea and Japan. In Korea, only one record, from 2003, was found on a website; none of the 240 fishermen who participated in the questionnaire reported seeing blue-lined octopus. However, a total of 31 observations of the blue-lined octopus from 2004 to July 2010 were found from 17 different regions in the East/Japan Sea and neighboring waters in Japan. Twenty-two cases were from coastal Honshu Island, and nine were from the west coast of Kyushu Island, Japan. The northern distributional boundary of the blue-lined octopus on the Japanese coast was off Fukui Prefecture around latitude $36^{\circ} 10^{\prime} \mathrm{N}$. Our results indicate that the blue-lined octopus is distributed extensively along the Japanese coast, at a low frequency, in the East/Japan Sea.
\end{abstract}

Key words: Blue-ringed octopus, Blue-lined octopus, Hapalochlaena spp., East/Japan Sea, Climate change, Internet

\section{Introduction}

Members of the octopus genus Hapalochlaena are characterized by small body size and iridescent blue markings on their dorsal surfaces and arms. Hapalochlaena is composed of three octopus species, H. fasciata, H. lunulata, and H. maculosa. All three are commonly called blue-ringed octopus because of their distinctive patterns of iridescent blue rings or lines, but $H$. fasciata is the blue-lined octopus, $H$. lunulata the greater blue-ringed octopus, and $H$. maculosa the lesser blueringed octopus (Norman, 1998).

Hapalochlaena spp. are equipped with venom in their posterior salivary glands that aids in the capture of prey, and con- tain tetrodotoxin in their soft tissues (Sheumack et al., 1978; Williams and Caldwell, 2009). Envenomation by these species has been responsible for human fatalities and should be treated urgently (Williamson et al., 1996; Cavazzoni et al., 2008; Williams, 2010). Two people died and 85 patients were hospitalized due to the consumption of blue-ringed octopus in southern Vietnam in 2004 (Agence France-Presse, 2004).

Among the Hapalochlaena species, the blue-lined octopus, $H$. fasciata, is commonly found in the waters off the coast of Australia but its range extends through the Pacific Ocean north to Japan (Williamson et al., 1996). Hapalochlaena fasciata
Open Access http://dx.doi.org/10.5657/FAS.2012.0001

This is an Open Access article distributed under the terms of the Creative Commons Attribution Non-Commercial License (http://creativecommons. org/licenses/by-nc/3.0/) which permits unrestricted non-commercial use, distribution, and reproduction in any medium, provided the original work is properly cited. pISSN: 2234-1749 eISSN: 2234-1757
Received 28 September 2011; $\quad$ Revised 28 November 2011; Accepted 27 January 2012

*Corresponding Author

E-mail:kimjihoe@korea.kr 


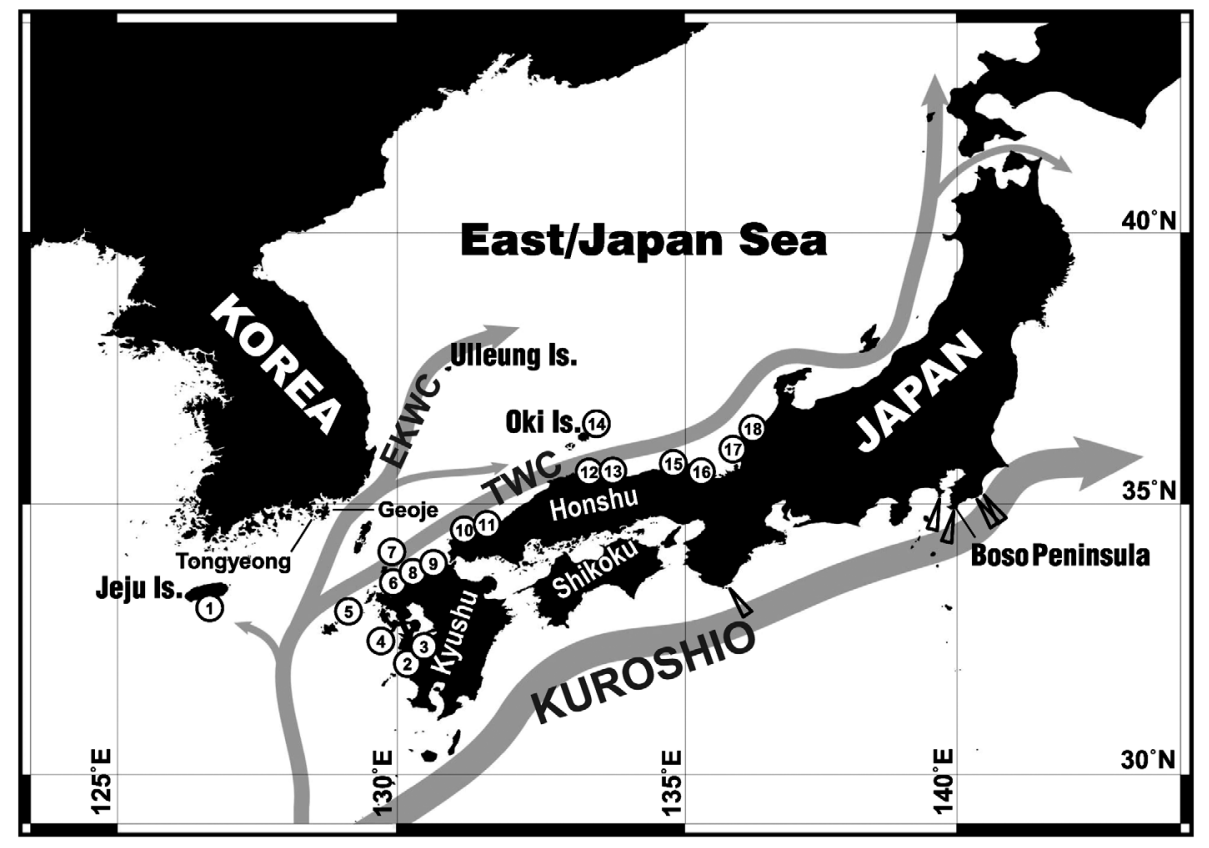

Fig. 1. Geographical distribution of the blue-lined octopus observed in the East/Japan Sea and adjacent waters and the general pattern of surface currents in the sea and neighboring waters. Acute angled triangles indicate geographical distribution of the blue-lined octopus along the Pacific coast of Honshu Island, Japan (from Kubodera, 1994). The localities of circled numbers correspond to the place numbers in Table 1. TWC, Tsushima Warm Current; EKWC, East Korean Warm Current.

was distributed north to the southern islands of the Japanese coast until the 1970s (Hashimoto, 1977), but the distributional boundary of the species moved northward to the Boso Peninsula (refer to Fig. 1) on the Pacific Coast of Honshu Island in the 1990s (Kubodera, 1994). Incidentally, a specimen of $H$. fasciata was found at the Oki Islands, Japan, in the East/Japan Sea in 2005 (Kohtsuka, 2006) and it was suggested that the octopus could have migrated into the East/Japan Sea.

Biotic and abiotic factors may influence the distribution of marine organisms (Kolar and Rahel, 1993; Bhattacharjee et al., 2009) and the distribution of cephalopods, including octopuses, can be affected by environmental factors (Boyle, 1990; Semmens et al., 2004; Pierce et al., 2008; Leite et al., 2009). Water temperature has a fundamental effect on physiological processes and the maintenance of homeostasis in aquatic animals (Venables et al., 1978; Hoegh-Guldberg and Bruno, 2010), and it is probably one of the most important factors influencing the distribution of octopuses (Collins, 2002; Chédia et al., 2010). Recent sea warming could cause a shift in the distribution of marine organisms from low-latitude regions toward the poles (Walther et al., 2002; Parmesan and Yohe, 2003; Perry et al., 2005). The East/Japan Sea is one of the most rapidly warming large marine ecosystems in the world (Belkin, 2009), and its warming is expected to cause migration of marine organisms from subtropical waters. Spread of the blue-lined octopus from adjacent subtropical water into the
East/Japan Sea could be a significant threat to Koreans and Japanese because the organism possesses a powerful toxin. Furthermore, coastal residents along the East/Japan Sea have no experience with the dangers of this species of octopus. Estimating the geographical distribution of the blue-lined octopus would be useful for public safety. However, there are very few published reports on the geographical distribution of the bluelined octopus in the East/Japan Sea, except for one specimen that was found on Oki Island, Japan (Kohtsuka, 2006).

Although direct survey techniques, such as visual surveys and fishing data, are more effective for estimating the spatial distribution of octopuses (Pierce and Guerra, 1994; Hill and Wilkinson, 2004; Leite et al., 2009), these methods require extensive field research and funding. We hypothesized that, because Internet use is widespread and there is common access to the Internet in Korea and Japan (International Telecommunication Union, 2010), information on websites may be used as basic data for a large-scale distribution survey of an organism.

In this study, we conducted a survey to determine the geographical distribution of the blue-lined octopus using Internet search engines and a questionnaire. Individual observation records of the blue-lined octopus were gathered from websites in Korea and Japan, and every datum was used to create a large-scale geographical distribution map in the East/Japan Sea. 


\section{Materials and Methods}

\section{Study area}

The East/Japan Sea is a semi-enclosed marginal sea surrounded by Korea, Japan, and Russia. It is connected to the adjacent ocean by shallow straits. Warm water originating from a branch of the Kuroshio Current, which is a strong warm current in the western North Pacific Ocean, flows into the East/ Japan Sea through the Korea/Tsushima Strait and flows out through the other straits (Cho and Kim, 2000; Kim et al., 2001; Taegue et al., 2006; Na et al., 2009). The Northwest Pacific Ocean, especially the East/Japan Sea, the East China Sea, and the Kuroshio Current, are the most rapidly warming marine environments in the world (Belkin, 2009). We designated the East/Japan Sea and adjacent waters as the survey area to determine changes in the distributional range of the blue-lined octopus in relation to climate change.

\section{Data collection}

Four commercially available internet search engines were used to find records on the Internet. Daum (http://www. daum.net/), Google Korea (http://www.google.co.kr/), Naver (http://www.naver.com/), and Yahoo! Korea (http://kr.yahoo. $\mathrm{com} /$ ) were used for Korean information; goo (http://www. goo.ne.jp/), Google Japan (http://www.google.co.jp/), MSN (http://jp.msn.com/), and Yahoo! Japan (http://www.yahoo. co.jp/) were used for Japanese information. The same search terms were entered in the search engines. Two words in the Korean language were entered at the same time in the Korean search engines because there is no common name for the bluelined octopus (or the blue-ringed octopus) in Korea. One word (Dok in Korean) meant toxin, poison or venom, and the other word (Muneo, Jukkumi, or Nakji in Korean) meant octopus. We also searched for "Hapalochlaena," "blue-ringed octopus," and "blue-lined octopus" in English on the Korean websites. In contrast, the common Japanese name of the blue-lined octopus is Hyomondako (Kubodera, 1994) and this was entered in the Japanese search engines. Among the results from Japan, information found from the prefectures along the west coast of Kyushu Island and Honshu Island, Japan (such as Kumamoto, Nagasaki, Saga, Fukuoka, Yamaguchi, Shimane, Tottori, Hyogo, Kyoto, and Fukui) was included. Regardless of the source (i.e., the government, the press, and private records, including scuba divers), all information was included. If the record was not complete, either lacking an observation date or place-name, the data were excluded. Overlapping information was considered to be a single case. The individual observation data were collected discontinuously from July 2009 to August 2010.

\section{Questionnaire administered to fishermen}

Korean fishermen living on the southeast coast of Korea, such as Tongyeong and Geoje, and Ulleung Island located in the East/Japan Sea, were surveyed during July and August 2010. The questionnaire participants were 145 fishermen from Tongyeong, 53 fishermen from Geoje, and 42 fishermen from Ulleung Island. Before starting the survey, we explained, with photographs, the general characteristics of the blue-lined octopus including body size, change in body color and the brilliant iridescent blue lines or blue rings.

\section{Results}

Internet reports of sightings of the blue-lined octopus around the East/Japan Sea are listed in Table 1; the locations were marked on a map and their geographical distribution is shown in Fig. 1. The circled numbers in Fig. 1 correspond to the place numbers in Table 1.

Overall, via the Internet, 32 sightings of the blue-lined octopus were found from 18 different regions in Korea and Japan. In Korea, there was some information on Hapalochlaena spp. on the Internet, but an actual record of the organism was found at only one website. The pictures taken at Jeju Island, Korea, in 2003 were from a solitary observation. The octopus in the picture taken at Jeju Island was recorded as $H$. fasciata on the website. Questionnaires to complement and enhance the base data targeted fishermen. However, none of the 240 fishermen questioned had observed a blue-lined octopus. Furthermore, none of the questionnaire participants knew that the blue-lined octopus existed or that an octopus can be dangerous.

In Japan, a total of 31 observation records of the blue-lined octopus were found on the Internet. Twenty-two cases were from the East/Japan Sea coast of Honshu Island, and nine cases were from the west coast of Kyushu Island (Table 2). The blue-lined octopus was first recorded along the Japanese coast of the East/Japan Sea in Maizuru Bay in 2004 (number 16 in Table 1 and Fig. 1). After this observation, the octopus was found in various regions on the East/Japan Sea side of Japan. The northern distributional boundary of the blue-lined octopus in the East/Japan Sea was off Sakai, Fukui Prefecture, Japan (around latitude $36^{\circ} 10^{\prime} \mathrm{N}$ ). Based on information from four websites, the blue-lined octopus was observed 14 times on Omi Island (numbers 11 to 24 in the Appendix 1), Yamaguchi Prefecture, located on the southwest coast of Honshu, Japan (number 10 in Fig. 1). Although observed depths and water temperatures were not recorded in every case, the bluelined octopus was found to a maximum depth of $19 \mathrm{~m}$ and in a water temperature range of $12-18^{\circ} \mathrm{C}$. Furthermore, a bluelined octopus, while brooding her eggs, was photographed four times on Omi Island from February to April 2009. These observations provide evidence of reproduction of the octopus in the East/Japan Sea. The blue-lined octopus was observed in all months of the year except September and October, but was found most frequently in April around the East/Japan Sea 
Table 1. List of internet records of the blue-lined octopus: observed regions and dates around the East/Japan Sea

\begin{tabular}{|c|c|c|c|c|c|c|}
\hline $\begin{array}{l}\text { Place } \\
\text { No. }\end{array}$ & Country & Observed region & $\begin{array}{c}\text { Observed } \\
\text { date }\end{array}$ & $\begin{array}{c}\text { Depth } \\
\text { (m) }\end{array}$ & $\begin{array}{c}\text { Water temp. } \\
\left({ }^{\circ} \mathrm{C}\right)\end{array}$ & Finder or confirmer \\
\hline 1 & Korea & Mun Islet, Seoguipo, Jeju & Aug. 7, 2003 & 4 & - & Confirmed by a researcher \\
\hline 2 & Japan & Ushibuka, Kumamoto & Jan. 9, 2005 & - & 17 & Private record \\
\hline 3 & $"$ & Tashikita, Kumamoto & Apr. 8, 2010 & - & - & Confirmed by a researcher \\
\hline 4 & $"$ & Nomozaki, Nagasaki & May 12, 2010 & - & - & Private record \\
\hline 5 & $"$ & Goto Islands, Nagasaki & Apr. 12, 2009 & - & - & Confirmed by an officer \\
\hline 6 & $"$ & Kakara Island, Karatsu, Saga & Jul. 6, 2010 & $3-4$ & - & Confirmed by a government officer \\
\hline 7 & $"$ & Iki Island, Nagasaki & Jun. 23, 2010 & - & - & Confirmed by a government officer \\
\hline \multirow[t]{2}{*}{8} & $"$ & Hakada Bay, Fukuoka & Apr. 17, 2004 & - & 14 & Private record \\
\hline & $"$ & $"$ & Nov. 30, 2009 & - & - & Confirmed by a government officer \\
\hline 9 & $"$ & Fukutsu, Fukuoka & Dec. 20, 2006 & - & 15 & Private record \\
\hline \multirow[t]{14}{*}{10} & $"$ & Omi Island, Nagatoshi, Yamaguchi & Jan. 29, 2005 & - & - & Private record \\
\hline & $"$ & $"$ & Dec. 20, 2007 & - & 16 & Private record \\
\hline & $"$ & $"$ & Mar. 15, 2008 & - & 13 & Private record \\
\hline & $"$ & $"$ & Apr. 13, 2008 & - & 14 & Private record \\
\hline & $"$ & $"$ & Apr. 23, 2008 & - & - & Private record \\
\hline & $"$ & $"$ & Dec. 3, 2009 & - & 18 & Private record \\
\hline & $"$ & $"$ & Feb. 3, 2009 & - & 14 & Private record \\
\hline & $"$ & $"$ & Feb. 5, 2009 & - & 14 & Private record \\
\hline & $"$ & $"$ & Feb. 28, 2009 & - & 14 & Private record (breeding) \\
\hline & $"$ & $"$ & Mar. 8, 2009 & - & 13 & Private record (breeding) \\
\hline & $"$ & $"$ & Apr. 4, 2009 & - & 14 & Private record (breeding) \\
\hline & $"$ & $"$ & Apr. 11, 2009 & & $15-16$ & Private record (breeding) \\
\hline & $"$ & $"$ & May 8, 2009 & - & 17 & Private record \\
\hline & $"$ & $"$ & Mar. 14, 2009 & - & 12 & Private record \\
\hline 11 & $"$ & Hagi, Yamaguchi & Jan. 27, 2008 & - & 13.3 & Private record \\
\hline 12 & $"$ & Mihokan, Matsue, Shimane & May 20, 2008 & - & - & Confirmed by a researcher \\
\hline 13 & $"$ & Yurihama, Tottori & Dec. 5, 2006 & $2-3$ & - & Collected by a researcher \\
\hline 14 & $"$ & Okinoshima Island, Shimane & Aug. 24, 2005 & 19 & & Article (15) \\
\hline 15 & $"$ & Takeno, Toyooka, Hyogo & Apr. 4, 2010 & 7 & - & Private record \\
\hline 16 & $"$ & Maizuru Bay, Kyoto & Mar. 17, 2004 & - & - & Collected by a researcher \\
\hline 17 & $"$ & Takasu, Fukui & Nov. 9, 2009 & - & - & Confirmed by a researcher \\
\hline 18 & $"$ & Mikuni, Sakai, Fukui & Jun. 18, 2010 & 15 & - & Confirmed by a researcher \\
\hline
\end{tabular}

The place number is represented as a circled number in Fig. 1.

Table 2. Number of blue-lined octopus observed cases by month on the coast of the East/Japan Sea and adjacent waters

\begin{tabular}{|c|c|c|c|c|c|c|c|c|c|c|c|c|c|c|}
\hline \multirow{2}{*}{ Sea } & \multirow{2}{*}{ Region } & \multicolumn{12}{|c|}{ Month } & \multirow{2}{*}{ Sum } \\
\hline & & Jan. & Feb. & Mar. & Apr. & May & Jun. & Jul. & Aug. & Sep. & Oct. & Nov. & Dec. & \\
\hline East/Japan Sea & Honshu Is. (Japan) & 2 & 3 & 4 & 5 & 2 & 1 & - & 1 & - & - & 1 & 3 & 22 \\
\hline \multirow[t]{2}{*}{ Adjacent water } & Jeju Is. (Korea) & - & - & - & - & - & - & - & 1 & - & - & - & - & 1 \\
\hline & Kyushu Is. (Japan) & 1 & - & - & 3 & 1 & 1 & 1 & - & - & - & 1 & 1 & 9 \\
\hline Sum & & 3 & 3 & 4 & 8 & 3 & 2 & 1 & 2 & - & - & 2 & 4 & 32 \\
\hline
\end{tabular}


(Table 2). We found that the blue-lined octopus was distributed extensively around the East/Japan Sea side of Japan. To the best of our knowledge, this is the first report on the large-scale geographical distribution of the blue-lined octopus around the East/Japan Sea.

\section{Discussion}

\section{Usefulness of the Internet for a large-scale distri- bution survey of the blue-lined octopus}

The Internet is a widespread source of information and its use is prevalent in Korea and Japan. In 2008, the percentage of households with access to the Internet in Korea and Japan was $94.3 \%$ and $79.8 \%$, respectively (International Telecommunication Union, 2010). Many observation records of the blue-lined octopus around the East/Japan Sea were gathered via the Internet. The Internet search method used here is not comparable to common systematic fisheries survey methods, such as fishing data or visual survey techniques (Pierce and Guerra, 1994; Hill and Wilkinson, 2004; Leite et al., 2009). A systematic survey of the blue-lined octopus over wide geographical regions is not easy because of its small size and because its skin color makes it almost invisible. Moreover, collection of accurate fishing data is difficult because there is no commercial fishery for the blue-lined octopus (Norman, 1998) and very little is known about its population density in specific areas. The results of our survey may not be sufficient as part of a public safety program, although they can provide useful information to warn of possible food poisoning or bites.

Through this study, we proved the usefulness of the Internet for a large-scale survey of the blue-lined octopus. In many cases, the date and place of observation or photos taken in the field of the blue-lined octopus were gathered. Species-specific features of the blue-lined octopus, such as iridescent blue lines on the dorsal mantle, can be observed in most of the octopus photos posted on the Internet. Country-specific commercial search engines were used in Korea and Japan. Some records were found by all search engines, while others were found only by some search engines. Several search engines were needed because different search engines provided different results. Similar results have been reported by other investigators who have compared the usefulness of Internet search engines for finding health information (Wu and Li, 1999; Merion et al., 2000).

\section{Geographical distribution of the blue-lined octo- pus around the East/Japan Sea and factors affect- ing its distribution}

The blue-lined octopus is found along the Pacific Coast of Honshu Island and the southern islands of Japan (Kubodera, 1994), but very little is known about the geographical distribu- tion of the octopus on the East/Japan Sea coast of the country. Global warming is expected to cause migration of the bluelined octopus from existing habitats, much the same as for fish (Walther et al., 2002; Parmesan and Yohe, 2003; Perry et al., 2005; Dulvy et al., 2008). Evidence of the spread of this octopus in the East/Japan Sea and adjacent waters was gathered in Korea and Japan. There was little evidence to suggest that this octopus occupies the Korean coast of the East/Japan Sea, contrary to expectations. However, considerable evidence supporting the existence of blue-lined octopus in the East/Japan Sea was collected from Japan. In addition to the records listed in Table 1, more data that lacked objective evidence, such as an observation date or location, were excluded from the Japan data. The excluded data did not affect the northern distributional boundary of the species because most of the incomplete data were obtained from regions south of southwestern Honshu Island, Japan.

We found four photos of a blue-lined octopus brooding eggs taken at Yamaguchi, Japan, on a website. This is obvious evidence that the blue-lined octopus is reproducing in the southern East/Japan Sea. We suggest that the southern East/Japan Sea has become a favorable reproductive environment for the blue-lined octopus. Brooding blue-lined octopuses were found at water temperatures between $13^{\circ} \mathrm{C}$ and $16^{\circ} \mathrm{C}$ (Table 1). Tranter and Augustine (1973) reported that the embryonic development time of the blue-lined octopus was about 2 months at seawater temperatures of $20.8-22.5^{\circ} \mathrm{C}$. The embryonic developmental period of Hapalochlaena spp. is temperature dependent: the higher the water temperature, the shorter the developmental period (Overath and von Boletzky, 1974). It is presumed that the embryonic development period of the bluelined octopus at $13-16^{\circ} \mathrm{C}$ will extend beyond 2 months.

Although biotic and abiotic factors affect the distribution of octopuses in the natural environment (Mather, 1982; Boyle, 1990; Collins, 2002; Semmens et al., 2004; Pierce et al., 2008; Leite et al., 2009; Chédia et al., 2010), the geographical distribution of the blue-lined octopus in the southern part of Japan is strongly influenced by the Kuroshio Current (Kubodera, 1994). The East/Japan Sea is also influenced by the Tsushima Warm Current, which is a branch of the Kuroshio Current. The distribution of the blue-lined octopus around the East/Japan Sea most likely corresponds to the flow of the Tsushima Warm Current along the Japanese coast (Fig. 1). The Tsushima Warm Current flows into the East/Japan Sea through the Korea/Tsushima Strait and then separates into two or three branches. One branch, called the East Korean Warm Current, flows along the east coast of Korea and one branch flows along the Japanese coast, while the offshore branch is seasonally variable (Kawabe, 1982; Cho and Kim, 2000). Southeast regions, such as Tongyeong, Geoje, and Ulleung Island in Korea, are also influenced by the Tsushima Warm Current, but no evidence of blue-lined octopus was collected from either Internet searches or questionnaires administered to local fishermen. Although the Tsushima Warm Current flows along the coasts of both 
Korea and Japan, there was a considerable difference in the distribution of the blue-lined octopus between the countries. We suggest that either the blue-lined octopus has received little attention in Korea or that there is another factor interrupting its settlement along the Korean coast.

The spread of the blue-lined octopus via water currents would be difficult because the octopus produces relatively large eggs and lacks a planktonic stage in its life history (Tranter and Augustine, 1973; Kubodera, 1994). Nevertheless, blue-lined octopus were found in large regions around the East/Japan Sea. This means that a part of the East/Japan Sea and adjacent waters may have changed to provide a suitable habitat for the blue-lined octopus, which originated in tropical and subtropical waters. The East/Japan Sea and the East China Sea around Korea and Japan are rapidly warming large marine ecosystems (Kim et al., 2001; Belkin, 2009). The net sea surface temperature increase in the East/Japan Sea and the East China Sea between 1982 and 2006 was $1.09^{\circ} \mathrm{C}$ and $1.22^{\circ} \mathrm{C}$, respectively (Belkin, 2009). The widespread distribution of the blue-lined octopus in the East/Japan Sea, originating from tropical or subtropical waters, is presumed to be caused by sea warming that occurred over a long period. Generally, pelagic species, especially fishes, are more sensitive to environmental change (including climate change) than benthos and demersal fish (Hiscock et al., 2004; Megrey et al., 2009; Rijnsdorp et al., 2009). Although the blue-lined octopus is a demersal species, the octopus was found at the relatively high northern latitude of $36^{\circ} 10^{\prime} \mathrm{N}$. We suggest that sea warming has contributed to a slow northward shift in the distribution of the blue-lined octopus. Models predict that the surface water temperature in the East/Japan Sea will be $1-6^{\circ} \mathrm{C}$ warmer in 2060 than at present (Murazaki et al., 2005). If the East/Japan Sea continues to warm, the blue-lined octopus will likely become more widespread, including along the Korean coast, especially along the southeast coast of the Korean Peninsula where it is significantly affected by the Tsushima Warm Current.

Recent sea warming is expected to cause migration of marine organisms from adjacent subtropical waters to the East/ Japan Sea. As we expected, the blue-lined octopus is widely distributed along the Japanese coast around the East/Japan Sea. Expansion of the range of the poisonous and venomous blue-lined octopus may increase human health risks. Invasion of the blue-lined octopus into the East/Japan Sea will increase concerns over health and food safety in Korea and Japan. Health and food safety authorities should educate the public on preventing food poisoning or envenomation by the bluelined octopus.

\section{Acknowledgments}

The authors would like to thank Dr. Wol-Ae Lim, a researcher in NFRDI and Mr. Gwan-Gyu Kim, an officer on U1leung Island, Korea, for their assistance in the questionnaire survey. This work was funded by a grant from the National Fisheries Research and Development Institute, Korea (RP2011-FS-020).

\section{References}

Agence France-Presse. 2004. Poisonous octopus leaves two dead in south Vietnam. Sarawak Tribune 22, June 2004 [Internet]. Jabatan Perkhidmatan Veterinar, Perak, MY, Accessed 29 Nov 2010, http:// www.jpvpk.gov.my/html/news/archives/English/June04\%2022a. htm.

Belkin IM. 2009. Rapid warming of large marine ecosystems. Prog Oceanogr 81, 207-213.

Bhattacharjee J, Haukos DA and Neaville J. 2009. Influence of biotic and abiotic factors on annual aboveground biomass of an intermediate coastal marsh. Wetlands 29, 690-696.

Boyle PR. 1990. Cephalopod biology in the fisheries context. Fish Res 8, 303-321.

Cavazzoni E, Lister B, Sargent P and Schibler A. 2008. Blue-ringed octopus (Hapalochlaena sp.) envenomation of a 4-year-old boy: a case report. Clin Toxicol (Phila) 46, 760-761.

Chédia J, Widien K and Amina B. 2010. Role of sea surface temperature and rainfall in determining the stock and fishery of the common octopus (Octopus vulgaris, Mollusca, Cephalopoda) in Tunisia. Mar Ecol 31, 431-438.

Cho YK and Kim K. 2000. Branching mechanism of the Tsushima Current in the Korea Strait. J Phys Oceanogr 30, 2788-2797.

Collins MA. 2002. Cirrate octopods from Greenland and Iceland waters. J Mar Biol Assoc U K 82, 1035-1036.

Dulvy NK, Rogers SI, Jennings S, Stelzenmüller V, Dye SR and Skjoldal HR. 2008. Climate change and deepening of the North Sea fish assemblage: a biotic indicator of warming seas. J Appl Ecol 45, 1029-1039.

Hashimoto Y. 1977. Marine Toxins. University of Tokyo Press, Tokyo, JP, pp. 195-198 (in Japanese).

Hill $\mathrm{J}$ and Wilkinson C. 2004. Methods for Ecological Monitoring of Coral Reefs: A Resource for Managers, Version 1. Australian Institute of Marine Science, Townsville, AU.

Hiscock K, Southward A, Tittley I and Hawkins S. 2004. Effects of changing temperature on benthic marine life in Britain and Ireland. Aquatic Conserv Mar Freshw Ecosyst 14, 333-362.

Hoegh-Guldberg O and Bruno JF. 2010. The impact of climate change on the world's marine ecosystems. Science 328, 1523-1528.

International Telecommunication Union. 2010. Measuring the Information Society 2010. ITU, Geneva, CH.

Kawabe M. 1982. Branching of the Tsushima Current in the Japan Sea. Part I: Data analysis. J Oceanogr Soc Jpn 38, 97-107.

Kim K, Kim KR, Min DH, Volkov Y, Yoon JH and Takematsu M. 2001. Warming and structural changes in the East (Japan) Sea: a clue to future changes in global oceans? Geophys Res Lett 28, 3293-3296.

Kohtsuka H. 2006. Record of blue-ringed octopus Hapalochlaena cf. fasciata (Mollusca: Cephalopoda) from Oki Islands, Sea of Japan. Bull Hoshizaki Green Found 9, 226. 
Kim et al. (2012) Northward Migration of the Blue-lined Octopus, Hapalochlaena spp.

Kolar CS and Rahel FJ. 1993. Interaction of a biotic factor (predator presence) and an abiotic factor (low oxygen) as an influence on benthic invertebrate communities. Oecologia 95, 210-219.

Kubodera T. 1994. Nihon-no Kishou-na Yasei Suisei Seibutsu-ni Kansuru Kiso Shiryon [Baseline Information on Scarce Wild Aquatic Life in Japan]. Suisanchyo [Fisheries Agency], Tokyo, JP, pp. 104111 (in Japanese).

Leite TS, Haimovici M, Mather J and Lins Oliveira JE. 2009. Habitat, distribution, and abundance of the commercial octopus (Octopus insularis) in a tropical oceanic island, Brazil: information for management of an artisanal fishery inside a marine protected area. Fish Res 98, 85-91.

Mather JA. 1982. Factors affecting the spatial distribution of natural populations of Octopus joubini robson. Anim Behav 30, 11661170.

Megrey BA, Hare JA, Stockhausen WT, Dommasnes A, Gjøsæter H, Overholtz W, Gaichas S, Skaret G, Falk-Petersen J, Link JS and Friedland KD. 2009. A cross-ecosystem comparison of spatial and temporal patterns of covariation in the recruitment of functionally analogous fish stocks. Prog Oceanogr 81, 63-92.

Merion RM, Merion DE and Haskin SS. 2000. Health information search metrics using popular internet search engines. In: Proceedings of AMIA Annual Symposium. Overhage JM, ed. Hanley \& Belfus, Inc., Philadelphia, PA, US, p. 1086.

Murazaki K, Sasaki H, Tsujino H, Takayabu I, Sata Y, Ishizaki H and Kurihara K. 2005. Climate change projection for the ocean around Japan using a high-resolution coupled atmosphere-ocean regional climate model. SOLA 1, 101-104.

Na H, Isoda Y, Kim K, Kim YH and Lyu SJ. 2009. Recent observations in the straits of the East/Japan Sea: a review of hydrography, currents and volume transports. J Mar Syst 78, 200-205.

Norman MD. 1998. Octopodidae, benthic octopuses. In: FAO Species Identification Guide for Fishery Purposes. The Living Marine Resources of the Western Central Pacific, Vol. 2. Cephalopods, Crustaceans, Holothurians and Sharks. Carpenter KE and Niem VH, eds. FAO, Rome, IT, pp. 800-826.

Overath H and von Boletzky S. 1974. Laboratory observations on spawning and embryonic development of a blue-ringed octopus. Mar Biol 27, 333-337.

Parmesan C and Yohe G. 2003. A globally coherent fingerprint of climate change impacts across natural systems. Nature 421, 37-42.

Perry AL, Low PJ, Ellis JR and Reynolds JD. 2005. Climate change and distribution shifts in marine fishes. Science 308, 1912-1915.
Pierce GJ and Guerra A. 1994. Stock assessment methods used for cephalopod fisheries. Fish Res 21, 255-285.

Pierce GJ, Valavanis VD, Guerra A, Jereb P, Orsi-Relini L, Bellido JM, Katara I, Piatkowski U, Pereira J, Balguerias E, Sobrino I, Lefkaditou E, Wang J, Santurtun M, Boyle PR, Hastie LC, MacLeod CD, Smith JM, Viana M, González AF and Zuur AF. 2008. A review of cephalopod-environment interactions in European Seas. Hydrobiologia 612, 49-70.

Rijnsdorp AD, Peck MA, Engelhard GH, Möllmann C and Pinnegar JK. 2009. Resolving the effect of climate change on fish populations. ICES J Mar Sci 66, 1570-1583.

Semmens JM, Pecl GT, Villanueva R, Jouffre D, Sobrino I, Wood JB and Rigby PR. 2004. Understanding octopus growth: patterns, variability and physiology. Mar Freshw Res 55, 367-377.

Sheumack DD, Howden ME, Spence I and Quinn RJ. 1978. Maculotoxin: a neurotoxin from the glands of the octopus, Hapalochlaena maculosa identified as tetrodotoxin. Science 199, 188-189.

Taegue WJ, Ko DS, Jacobs GA, Perkins HT, Book JW, Smith SR, Chang KI, Suk MS, Kim K, Lyu SJ and Tang TY. 2006. Currents through the Korea/Tsushima Strait: a review of LINKS observations. Oceanography 19, 50-63.

Tranter DJ and Augustine O. 1973. Observations on the life history of the blue-ringed octopus Hapalochlaena maculosa. Mar Biol 18, 115-128

Venables BJ, Fitzpatrick LC and Pearson WD. 1978. Acclimation temperature and temperature tolerance in fingerling largemouth bass (Micropterus salmoides). Environ Pollut 17, 161-165.

Walther GR, Post E, Convey P, Menzel A, Parmesan C, Beebee TJC, Fromentin JM, Hoegh-Guldberg O and Bairlein F. 2002. Ecological responses to recent climate change. Nature 416, 389-395.

Williams BL. 2010. Behavioral and chemical ecology of marine organisms with respect to tetrodotoxin. Mar Drugs 8, 381-398.

Williams BL and Caldwell RL. 2009. Intra-organismal distribution of tetrodotoxin in two species of blue-ringed octopuses (Hapalochlaena fasciata and H. lunulata). Toxicon 54, 345-353.

Williamson JA, Fenner PJ, Burnett JW and Rifkin JF. 1996. Venomous and Poisonous Marine Animals: A Medical and Biological Handbook. University of New South Wales Press/Fortitude Valley Queensland, Surf Life Saving Queensland Inc., Sydney, AU, pp. 330-336.

Wu G and Li J. 1999. Comparing Web search engine performance in searching consumer health information: evaluation and recommendations. Bull Med Libr Assoc 87, 456-461. 
Appendix 1. Summary of records' source of the blue-lined octopus observed around the East/Japan Sea

\begin{tabular}{|c|c|c|c|c|}
\hline No. & Observed date & Observed place & Information sources (address) & Accessed date \\
\hline 1 & Aug. 7, 2003 & Mun Islet, Seoguipo, Jeju & $\begin{array}{l}\mathrm{http}: / / \text { microseashell.com } / \mathrm{bbs} / \mathrm{view} . \mathrm{php} ? \mathrm{id}=\text { Cephalopoda\&p } \\
\text { age }=1 \& \mathrm{sn} 1=\& \text { divpage }=1 \& \mathrm{sn}=\mathrm{off} \& \mathrm{ss}=\mathrm{on} \& \mathrm{sc}=\text { on\&select_ } \\
\text { arrange }=\text { headnum } \& \text { desc }=\text { asc } \& \text { no }=11\end{array}$ & Jul. 16, 2009 \\
\hline 2 & Jan. 9, 2005 & Ushibuka, Kumamoto & $\begin{array}{l}\text { http://www.blue-earth.co.jp/sealog/sealog. } \\
\text { cgi?mode=\&pass=\&log=200501 }\end{array}$ & Apr. 8, 2010 \\
\hline 3 & Apr. 8, 2010 & Tashikita, Kumamoto & http://bbs1 aimix-z.com/gbbs.cgi?room=33kai\&page $=25$ & Jul. 22, 2010 \\
\hline 4 & May 12,2010 & Nomozaki, Nagasaki & http://ootorimaru.com/mt-mobile/archives/cat2/ & Aug. 9, 2010 \\
\hline 5 & Apr. 12, 2009 & Goto Islands, Nagasaki & http://official.shinkamigoto.net/index.php?itemid=705 & Apr. 8, 2010 \\
\hline 6 & Jul. 6, 2010 & Kakara Island, Karatsu, Saga & http://www.city.tosu.lg.jp/1812.htm & Aug. 9, 2010 \\
\hline 7 & Jun. 23, 2010 & Iki Island, Nagasaki & http://www.nishinippon.co.jp/nnp/item/180207 & Jul. 22, 2010 \\
\hline 8 & Apr. 17, 2004 & Hakada Bay, Fukuoka & http://www.kunitomi-div.com/ours/diving/log/2004/04log14.htm & Apr. 8, 2010 \\
\hline 9 & Nov. 30, 2009 & $"$ & http://www.nishinippon.co.jp/nnp/item/169950 & Apr. 8, 2010 \\
\hline 10 & Dec. 20, 2006 & Fukutsu, Fukuoka & http://blog.f-diving.net/index.php?blogid=3907\&archive=2006-12 & Apr. 8, 2010 \\
\hline 11 & Jan. 29,2005 & Omi Is. Nagatoshi, Yamaguchi & http://www.sea-again.net/sea2/divlog/div05/divlog05012904.htm & Apr. 8, 2010 \\
\hline 12 & Dec. 20. 2007. & $"$ & http://dijisanpo.blog.ocn.ne.jp/seaagain/2007/12/index.html & Aug. 12, 2010 \\
\hline 13 & Mar. 15, 2008 & $"$ & http://dijisanpo.blog.ocn.ne.jp/seaagain/2008/03/index.html & Aug. 12, 2010 \\
\hline 14 & Apr. 13, 2008 & $"$ & http://dijisanpo.blog.ocn.ne.jp/seaagain/2008/04/index.html & Aug. 12, 2010 \\
\hline 15 & Apr. 23, 2008 & $"$ & http://goma-mongara.net/webL/fish/hyoumondaiko.htm & Apr. 8, 2010 \\
\hline 16 & Dec. 3, 2008 & $"$ & http://dijisanpo.blog.ocn.ne.jp/seaagain/2008/12/index.html & Aug. 12, 2010 \\
\hline 17 & Feb. 3, 2009 & $"$ & http://dijisanpo.blog.ocn.ne.jp/seaagain/2009/02/index.html & Aug. 12, 2010 \\
\hline 18 & Feb. 5, 2009 & $"$ & http://dijisanpo.blog.ocn.ne.jp/seaagain/2009/02/index.html & Aug. 12, 2010 \\
\hline 19 & Feb. 28, 2009 & $"$ & http://dijisanpo.blog.ocn.ne.jp/seaagain/2009/02/index.html & Aug. 12, 2010 \\
\hline 20 & Mar. 8, 2009 & $"$ & http://dijisanpo.blog.ocn.ne.jp/seaagain/2009/03/index.html & Aug. 12, 2010 \\
\hline 21 & Apr. 4, 2009 & $"$ & http://dijisanpo.blog.ocn.ne.jp/seaagain/2009/04/index.html & Aug. 12, 2010 \\
\hline 22 & Apr. 11, 2009 & $"$ & http://dijisanpo.blog.ocn.ne.jp/seaagain/2009/04/index.html & Aug. 12, 2010 \\
\hline 23 & May 8, 2009 & $"$ & http://www.vox-plus.com/scuba_blog/0508.php & Aug. 8, 2010 \\
\hline 24 & Mar. 14, 2010 & $"$ & http://dijisanpo.blog.ocn.ne.jp/seaagain/2009/04/index.html & Aug. 12, 2010 \\
\hline 25 & Jan. 27, 2008 & Hagi, Yamaguchi & http://www.umizoh.com/nikki08/0801gatu.html & Apr. 8, 2010 \\
\hline 26 & May 20, 2008 & Mihokan, Matsue, Shimane & http://www.pref.tottori.lg.jp/dd.aspx?itemid=271034 & Apr. 8, 2010 \\
\hline 27 & Dec. 5, 2006 & Yurihama, Tottori & $\begin{array}{l}\text { http://db.pref.tottori.jp/Press2.nsf/0/2eaca01b8485eff14925723d003ede } \\
\text { 60?OpenDocument }\end{array}$ & Apr. 8, 2010 \\
\hline 28 & Aug. 24, 2005 & Okinoshima Island, Shimane & http://jglobal.jst.go.jp/public/20090422/200902268867007223 & Jul. 22, 2010 \\
\hline 29 & Apr. 4, 2010 & Takeno, Toyooka, Hyogo & http://sankei.jp.msn.com/life/trend/100413/trd1004130130000-n1.htm & Jul. 22, 2010 \\
\hline 30 & Mar. 17, 2004 & Maizuru Bay, Maizuru, Kyoto & http://www.maipress.co.jp/kako/04nen3gatutpx.html & Apr. 8, 2010 \\
\hline 31 & Nov. 9, 2009 & Takasu, Fukui & http://www.nature.museum.city.fukui.fukui.jp/gallery/gallery.html & Apr. 8, 2010 \\
\hline 32 & Jun. 18, 2010 & Mikuni, Sakai, Fukui & http://osaka.yomiuri.co.jp/animal/genre8/20100622-OYO8T00386.htm & Aug. 9, 2010 \\
\hline
\end{tabular}

